\title{
THERAPEUTIC BUDGET MODELLING: A POSSIBLE ROAD TO BUDGETARY ALLOCA- TIONS IN THE PUBLIC HEALTH CARE SETTING
}

\section{Mr George K John}

B Pharm, M Pharm (Pharmacy Practice)

Senior Lecturer, Pharmacy Practice, School of Pharmacy, Faculty of Health Sciences, North-West University (Potchefstroom Campus), Potchefstroom

Corresponding author: George.John@nwu.ac.za

\section{Prof Martie S Lubbe}

B Pharm, M Pharm, PhD (Pharmacy Practice), DTE

Associate Professor: Head of Pharmacy Practice, School of Pharmacy, Faculty of Health Sciences, North-West University (Potchefstroom Campus), Potchefstroom

\section{Prof Jan HP Serfontein}

B Pharm, MBA, PhD (Pharmacy Practice)

Associate Professor: Head of Pharmaceutical Solutions through Research and Education, School of Pharmacy, Faculty of Health Sciences, North-West University (Potchefstroom Campus), Potchefstroom

Keywords: therapeutic budget model; Cost Prevalence Index (CPI); medicine usage patterns; average medicine cost; public primary health care clinics

\begin{abstract}
In South Africa, $70 \%$ of the country's population is dependent on the public health care sector (especially the primary health care structure) for their basic health care needs. The objective of the study is to analyse the cost and usage-related perspectives of medicines, to formulate a therapeutic budget model, for use as a planning and control instrument in the usage of medicines at a public primary care level. Data utilised in this study were obtained from patient records of six local primary health care clinics [ $N=1313]$ in Potchefstroom over a 24-day period. The medicines used by these patients were coded using the proposed medicine classification system. The average cost of medicines per consultation was $R 8.25 \pm 10.98$ [ $N=R 19669.50]$ for all medicines. The average cost per medicine item was $R 4.19 \pm 9.54$ [ $N=4$ 691] for all medicines [ $N=R 19$ 669.50]. Of the main groups of medicines issued to patients in the clinics, those displaying a total cost of treatment and usage of $\geq 5 \%$, constituted $88.20 \%$ and $84.08 \%$ of the total medicines used [ $N=4$ 691] respectively. From the study it was projected that $R 2607357.00$ (231.23\% more than the actual budget allocation) is needed for the optimal functioning and management of the six clinics in Potchefstroom. It is foreseen that compiling of a therapeutic budget modelling system would significantly help the public sector to prepare and plan budgetary policies for better medicine formulary and resource management.
\end{abstract}

\section{OPSOMMING}

In Suid-Afrika is $70 \%$ van die land se bevolking van die openbare gesondheidsorgsektor (veral die primêre gesondheidsorgstruktuur) afhanklik vir hulle basiese behoeftes aan gesondheidsorg. Die doel van hierdie studie was om die perspektiewe op die koste en gebruik van medisyne te ontleed, om 'n model gebaseer op terapeutiese klassifikasie vir ' $n$ begroting te formuleer wat as ' $n$ instrument vir beplanning en beheer van die gebruik van medisyne op die vlak van primêre sorg aangewend kan word.Die data wat in hierdie studie gebruik is, is uit die rekords van pasiënte van ses plaaslike primêregesondheidsorgklinieke [ $N=1313]$ in Potchefstroom oor ' $n$ periode van 24 dae verkry. Die medisyne wat deur hierdie pasiënte gebruik is, is volgens die voorgestelde klassifikasiestelsel vir medisyne gekodeer. Die gemiddelde koste van medisyne per konsultasie was $R 8.25 \pm 10.98$ [N=R19 669.50] vir alle medisyne. Die gemiddelde koste per medisyne-item was $R 4.19 \pm 9.54$ [N=4 691] vir alle medisyne [N=R19 
669.50].

Van die hoofgroepe medisyne wat in die klinieke aan pasiënte uitgegee word, het dié wat 'n totale koste van behandeling en gebruik van $\geq 5 \%$ bedra onderskeidelik $88.20 \%$ en $84.08 \%$ van die totale hoeveelheid gebruikte medisyne uitgemaak [ $N=4$ 691]. Uit hierdie studie is geprojekteer dat $R 2607357.00$ (231.23\% meer as die werklike toegekende begroting) nodig is vir die optimale werking en bestuur van die ses klinieke in Potchefstroom. Dit word voorsien dat die opstel van ' $n$ modelleerstelsel vir 'n begroting gebaseer op terapeutiese klassifikasie die openbare sektor beduidend kan help om beleid vir begroting met beter beheer van medisyne en hulpbronne voor te berei en te beplan.

\section{INTRODUCTION}

Although South Africa has made substantial progress in ensuring equity in the primary health care service provision, the country still faces a major challenge (Committee of Inquiry, 1995:6), as the public health structure does not provide for a proper monitoring system to measure the rate at which medicine is being distributed or to statistically determine and document the balance between demand, procurement, and expenditure. In the absence of this system, medicine distribution is seriously affected (DSM workshop, 2001a). Budgets allocated to provinces in South Africa are without guidance and statistical data thus hindering calculation of actual requirements (Blok, Zweygarth \& Summers, 2002:32). In most of the provinces, budget allocations do not necessarily correlate with the actual expenditure, as the budgets are usually calculated based upon the historical allocations (Blok et al. 2001:32). This has caused scenarios where funds are exhausted prematurely, causing a deficit. Therefore it affects the effective and efficient rendering of other crucial health care services. Buch (2000:57) observed that the inequity is also compounded by other factors including reduction in health budgets, a high inflation rate, low staff morale; all these despite substantial moves having been made in ensuring equity in the primary health care service provision in South Africa (Van Rensburg, Viljoen, Heunis, Van Rensburg \& Fourie, 2000:3). Medicine usage patterns in the public health care sector can be directly related to the efficiency of the distribution system, which is dependent on the financial allocation and expenditure in the public sector.

According to the Department of Finance's Medium-Term Expenditure Framework (MTEF) database, the total government expenditures for all ministries increased from R 158 billion in 1995/96 to R174 billion in 1996/97, and was projected to increase to R 240 billion by 2001 . According to McIntyre, Baba and Makan (1998:30), this in real terms would mark a decline in the per capita expenditure, since the expenditure increase did not take into account factors such as rapid population increase and inflation rates. McIntyre et al. (1998:31) calculated the decline to be R3 960 in 1995/96 to R3 720 in 2000/ 01 . For health care, expenditure increased from R16.5 billion in 1995/96 to R22.1 billion in 1997 and was projected to increase to R26.4 billion in 2000/01.

The 1995/96 national health services budget accounted for approximately $10 \%$ of total government expenditure, and it was estimated that in $2000 / 01$ it would be $11 \%$ (Mclntyre et al. 1998:31), it was thus necessary to have a reliable method to improve allocative efficiency of budgets. During the 2000/01 financial year, for the months of October and November, R1.66 billion was spent on national health services. Out of this amount, the North West Province spent R151.95 million for the same period (Coetzer, 2002). During the same period in 2001, the pharmaceuticals and surgicals budget expenditure for the North West Province was R12.66 million (Department of Health, 2001b).

If we look at the current trends and budget allocations, there has not been much change since 1995. According to the Health System Trust (2004b), the per capita health expenditure (amount spent on health per person) was R529.00 (in Rands). For the public sector, this is often calculated for the population without medical aid coverage (public sector dependent population), while for the private sector this is usually calculated for the number of medical schemes beneficiaries. The percentage of national Gross Domestic Product (GDP) that was spent on health care in 2001 was $8.8 \%$. With this picture in mind, it is therefore necessary to have a reliable method to improve the budget allocation efficiency. This study proposes a model which might bring such efficiency and provide a correlation between the budget and the medical expenditure, thus corroborating Mclntyre's suggestion that it is necessary to have a 
uniform and reliable method to forecast resource allocation in the public health care sector (Mclntyre et al. 1998).

In the financial year 2005/06, the nine provinces spent on average $98 \%$ or R214.8-billion of their adjusted budgets of R219.2-billion in 2005/06. According to the National Treasury, the expenditure on health totalled R46.9-billion or $99.5 \%$ of the R47.2-billion total adjusted budget for health, and was the third-largest (21.39\%), after education and social development, on provincial budgets (Mail \& Guardian, 2006). The spending pattern reflected a $16.6 \%$ or R6.7-billion increase compared with audited spending in 2003/04 (Manuel, 2004:13).

In line with the issue that this paper seeks to address, a Public Health Conference (PHASA, 2006) with the theme "making health systems work" was held in May 2006. In his paper at the conference Blecher (2006), revealed that South Africa had the highest Gross Domestic Product (GDP) expenditure, at 8.5\%. He argued that there was a need to introduce new financial management principles, and referred to the new buzz word "stewardship in health care financial management" to emphasise his point. Blecher was in fact echoing Kirigia (2005:5), speaking from the World Health Organization's (WHO) perspective for Africa, that health systems should be one of the critical areas to be monitored as "the effectiveness of public health programmes largely hinges on the effectiveness of the underlying health system".

It is worth pointing out that some of the views expressed above are partly realised in the strategic priorities for the South African National Health Systems 2004-2009 (SAHR, 2005:13). Of the key activities that were specified in the priorities were planning, budgeting, monitoring and evaluation with specific reference to strengthening health planning and budgeting and also to strengthening the use of a health information system (SAHR, 2005:15). This is because, in South Africa, 70\% of the population depends on the public health sector for their basic health care needs (John, 2003).

\section{DEFINITION OF TERM}

Therapeutic budget model: The therapeutic budget model aids in identifying areas of specific needs in the medicine demand-procurement-expenditure chain. The therapeutic budget model is based on detailed classification of all medicine items available in the public health care facilities, according to the therapeutic function (see Table 1). The proposed classification system would help in identifying areas of specific need. This helps the managers responsible for budgets, to achieve better control and estimation of projected budgetary allocations for the public health care facilities, based on actual medicine demand-procurement and expenditure data.

\section{OBJECTIVE}

The objective of this study was to formulate a therapeutic budget model to be used as a planning and control instrument based on the actual usage of medicines at a primary care level in the public sector in Potchefstroom. This model would serve the purpose of aiding the role players in the public health care system not only in preparing and planning budgetary policies for better formulary and resource management, but also in evaluating the operational and clinical policies in an accurate manner.

\section{RESEARCH DESIGN}

The WHO model on the action programme on essential drugs (WHO, 1993:11), which is used for investigating medicine use in health facilities, was adopted as the model for this study with regard to the method used for data collection. A retrospective sample of patients visiting six local authority primary health care clinics in Potchefstroom from 25 September to 26 October (24 working days) ( $\mathrm{N}=1313)$ was selected (see Table 2). The total number of patients who visited the clinics during the study period was 15240 (see Table 2). Since the numbers of patients were many for the scope of the study, the patients were chosen based upon a $10 \%$ stratified sampling system. The reason for choosing a $10 \%$ sample population was borrowed from Neuman $(2000: 217)$ who postulates that if the sample size is a moderately large one $(\mathrm{N}=10000)$ a smaller sampling ratio of $10 \%$ would be sufficient.

Care was taken to ensure that there was minimal disturbance or disruption to the normal activities in the clinics. The researcher went to each clinic and first of all selected the sample population by inspecting the 
different patient registers and selecting every tenth patient (thus a $10 \%$ systematic sampling is obtained) from each category for the specified period. The accuracy of the gathered data was further enhanced by the personnel of each clinic doing a random cross check of about six to ten survey forms each day.

The study was conducted in two phases; the pilot phase and the main study. The data were collected using a structured survey form, which was formulated by the researcher in consultation with academics from various health disciplines as well as members of the primary health care clinics in Potchefstroom. During the pilot visit the survey form was pre-tested (twenty patients' files were selected based on the sampling method and the information in the patient files were recorded onto the survey form) and all flaws on the survey form were corrected. The patient files which were used in the pilot visit were not used again for the main study. One of the public primary health care clinics of the intended study was used for the pilot visit; this was due to the fact that all public primary health care clinics in the Potchefstroom health district were used for the scope of the main study. The emphasis of the pilot visit was to test the reliability of the sampling method and the validity of the survey form.

The patients were not identified by their names on the survey form, rather the selected patients were assigned a Patient Identification Number (PIN) in line with Neuman's (2000:99) principle of maintaining anonymity and confidentiality. This procedure was followed so as not to violate the Patients Rights Charter (Department of Health, 2004a) and the ethical considerations that are associated with operational research like psychological and legal jeopardy (Neuman, 2000:92), the maintenance of social etiquettes and a professional code of ethics (Leedy, 1997:116). The SAS $®$ system for Windows $\circledR$ (8.2, 2002 version) was used to create the database and to analyse the data by calculating certain descriptive and inferential statistics. The descriptive statistics were frequency tables, percentage expressions, mean value and standard deviation (Steyn, Smit, Du Toit \& Strasheim, 1999:6). The Cost Prevalence Index (here after referred to as $\mathrm{CPI}$ ) is the value obtained when the percentage cost is divided by the percentage frequency of the respective medicine items. If the value of CPI is $\geq 1.5$ then the medicine is considered to be expensive and needs further investigation
(Serfontein, 2004).

The medicines used by these patients were coded using the proposed medicine Budget Group (BG) (broad general classification), pharmacological groups (active therapeutic class), individual item descriptions with the strength and pre-pack form (this is to differentiate each medicine item as there could be more than one medicine item with the same individual ingredient) and the ATC (Anatomic Therapeutic Chemical) classification system (see Table 1). The diagnoses (based on the ICD-10 coding system) observed in the clinics were also included.

The proposed coding system (see Table 1) can be explained as follows: the first level is the budget group, which contains the main group to which the drug belongs; the second level is the pharmacological/therapeutic group under which the therapeutic entity is listed; the third level has the therapeutic subgroup with the chemical substance and the dose, pre-pack and nature of dosage form; the fourth level indicates the level of health care (in other words, $1=$ Primary health care, 2 = Secondary health care, $3=$ Tertiary health care) and the fifth level indicates the classification of the category of indications to which the drug belongs according to the Essential Drugs Programme (EDP) of South Africa as applied in primary health care as follows.

An example of a preparation containing Diazepam can be classified according to the proposed coding system as

$5 \quad$ First level-budget group - functional

07 Second level - therapeutic group-hypnotic/ sedatives

061 Third level-product identification/individual medicine item - Diazepam10 mg/2 ml injection - chemical substance and dose

1 Fourth level - level of health care - primary health care

N05 Fifth level - EDL classification of indication Psycholeptics

Thus the preparation containing Diazepam has the code 5-07-061-1-N05 according to the proposed classification system. 
Table 1: Proposed coding system

\begin{tabular}{|l|l|l|l|l|l|l|l|}
\hline Code & $\begin{array}{l}\text { Budget } \\
\text { Group } \\
\text { (B.G) }\end{array}$ & Code & $\begin{array}{l}\text { Pharmacological/ } \\
\text { Therapeutic group }\end{array}$ & Code & $\begin{array}{l}\text { Product } \\
\text { description }\end{array}$ & $\begin{array}{l}\text { Level } \\
\text { of } \\
\text { health } \\
\text { care }\end{array}$ & $\begin{array}{l}\text { ATC } \\
\text { Code }\end{array}$ \\
\hline 5 & Functional & 07 & Hypnotic/sedatives & 061 & $\begin{array}{l}\text { Diazepam 10 } \\
\text { mg/2 ml } \\
\text { injection }\end{array}$ & 1 & N05 \\
\hline
\end{tabular}

\section{RESULTS}

The three major areas under which the results will be enumerated are the following:

- General analyses

- Diagnoses analyses

- Medicine analyses

The conclusions drawn from the three respective major areas mentioned above are discussed simultaneously with the results, for better inferencing and assimilation capacity.

\section{General analyses}

When the different general parameters (as mentioned in Table 2) in the clinics are evaluated, a broad picture of what happens in the public primary health care clinics is revealed.

\section{Conclusions based on general param- eters}

With reference to Table 2, when the general parameters are evaluated in all the clinics in Potchefstroom health district, the following salient trends were observed:

- The most common dosage form for medicines issued in all the clinics was tablets $(65.4 \%)$.

- Medicine was supplied to the patients in $96.51 \%$ of the consultations in all the clinics.

- The most common dosage regimens prescribed in all the clinics were once daily (o.d), one thrice daily (t.i.d) and one stat. They comprised $46.58 \%$ of all dosage regimens prescribed.

\section{Diagnoses analyses}

When the general parameters are evaluated, based on criteria of diagnoses in the clinics, (prevalance, cost, gender, CPI and age group), a broad picture of what happens in the public primary health care clinics in terms of diagnoses is revealed. The above parameters are depicted in Table 3.

\section{Conclusions based on the diagnoses analysis}

Based on the analysis of Table 3, which shows the disease prevalence patterns in all the clinics in Potchefstroom health district, the following conclusion were reached:

- The average cost of medicine therapy for hypertension as a diagnosis was high when compared to the average cost for all diagnoses (R5.86 \pm 8.19 ), especially with a high CPI of 2.91 .

- The age group of $>12<19$ years has a higher incidence of prevalence (43.24\%) for the condition, family planning.

- The five diagnoses/conditions/diseases above constituted $69.50 \%$ (2 333 items) of medicines issued and $62.77 \%$ (R12 346.99) of medicine costs for all diagnoses in the clinics.

\section{Medicine analysis}

The general parameters were evaluated and analysed within the framework of a therapeutic budget model on cost-related aspects. From this evaluation and analyses we get a clear picture of the state of affairs in respect to medicine usage and cost patterns in the public 
Table 2: General parameter analyses

\begin{tabular}{|c|c|c|c|c|c|c|c|}
\hline \multicolumn{4}{|c|}{$\begin{array}{l}\text { Parameter } 1 \text { - Gender distribution of all } \\
\text { patients }\end{array}$} & \multicolumn{4}{|c|}{$\begin{array}{l}\text { Parameter } 2 \text { - Gender distribution of all } \\
\text { patients for all consultations }\end{array}$} \\
\hline Male & $\begin{array}{l}342 \\
\text { patients }\end{array}$ & $26.04 \%$ & & Male & $\begin{array}{l}1195 \\
\text { patients }\end{array}$ & $42.63 \%$ & \\
\hline Female & $\begin{array}{l}971 \\
\text { patients }\end{array}$ & $73.95 \%$ & & Female & $\begin{array}{l}1608 \\
\text { patients }\end{array}$ & $57.37 \%$ & \\
\hline \multicolumn{8}{|c|}{ Parameter 3 - Age group distribution of patients in all consultations } \\
\hline $\begin{array}{l}0<6 \\
\text { years }\end{array}$ & $\begin{array}{l}251 \\
\text { patients }\end{array}$ & $\begin{array}{l}>6<12 \\
\text { years }\end{array}$ & $\begin{array}{l}34 \\
\text { patients }\end{array}$ & $\begin{array}{l}>12<19 \\
\text { years }\end{array}$ & $\begin{array}{l}62 \\
\text { patients }\end{array}$ & $\begin{array}{l}>19<40 \\
\text { years }\end{array}$ & $\begin{array}{l}525 \\
\text { patients }\end{array}$ \\
\hline $\begin{array}{l}>40<60 \\
\text { years }\end{array}$ & $\begin{array}{l}218 \\
\text { patients }\end{array}$ & $>60$ years & $\begin{array}{l}98 \\
\text { patients }\end{array}$ & $\begin{array}{l}\text { Age } \\
\text { group } \\
\text { unknown }\end{array}$ & $\begin{array}{l}125 \\
\text { patients }\end{array}$ & & \\
\hline \multicolumn{8}{|c|}{ Parameter 4 - Type of patient consultation (all consultations, patient visit more than once) } \\
\hline $\begin{array}{l}\text { New } \\
\text { cases }\end{array}$ & $\begin{array}{l}364 \\
\text { patients }\end{array}$ & Follow-up & $\begin{array}{l}1991 \\
\text { patients }\end{array}$ & $\begin{array}{l}\text { Patient } \\
\text { record } \\
\text { not } \\
\text { available }\end{array}$ & $\begin{array}{l}329 \\
\text { patients }\end{array}$ & $\begin{array}{l}\text { Re- } \\
\text { treatment }\end{array}$ & $\begin{array}{l}112 \\
\text { patients }\end{array}$ \\
\hline \multicolumn{8}{|c|}{ Parameter 5 - Medicine supply during consultations } \\
\hline $\begin{array}{l}\text { Medicine } \\
\text { supplied }\end{array}$ & $96.51 \%$ & $\begin{array}{l}3240 \\
\text { Consulta- } \\
\text { tions }\end{array}$ & $\begin{array}{l}\text { Medicine } \\
\text { not } \\
\text { supplied }\end{array}$ & $3.49 \%$ & $\begin{array}{l}117 \\
\text { Consulta- } \\
\text { tions }\end{array}$ & & \\
\hline \multicolumn{8}{|c|}{ Parameter 6 - Reasons why medicine was not supplied } \\
\hline $\begin{array}{l}\text { Patient } \\
\text { given } \\
\text { advice } \\
\text { only }\end{array}$ & $\begin{array}{l}69 \\
\text { patients } \\
(58.47 \%)\end{array}$ & $\begin{array}{l}\text { Patient } \\
\text { referred } \\
\text { to hospital }\end{array}$ & $\begin{array}{l}27 \\
\text { patients } \\
(22.88 \%)\end{array}$ & $\begin{array}{l}\text { Patient } \\
\text { awaiting } \\
\text { diagnos- } \\
\text { tic tests } \\
\text { results }\end{array}$ & $\begin{array}{l}22 \\
\text { patients } \\
(18.64 \%)\end{array}$ & $\begin{array}{l}\text { No stock of } \\
\text { medicine }\end{array}$ & $\begin{array}{l}0 \text { inciden- } \\
\text { ces }\end{array}$ \\
\hline
\end{tabular}




\begin{tabular}{|c|c|c|c|c|c|c|c|}
\hline \multicolumn{8}{|c|}{ Parameter 7 - Dosage regimen distribution for all medicines prescribed in the clinics } \\
\hline $0 . d^{\nabla}$ & $\begin{array}{l}930 \\
\text { items }\end{array}$ & 1 b.d & $\begin{array}{l}366 \\
\text { items }\end{array}$ & 1 t.i.d. & $\begin{array}{l}528 \\
\text { items }\end{array}$ & 1/4 daily & 01 item \\
\hline 2 o.d & $\begin{array}{l}356 \\
\text { items }\end{array}$ & 2 b.d & 41 items & 2 t.i.d. & 36 items & $1 / 2$ daily & 40 items \\
\hline 3 o.d & $\begin{array}{l}341 \\
\text { items }\end{array}$ & 3 b.d & 02 items & 3 t.i.d. & 05 items & 1 p.r.n. ${ }^{\oplus}$ & 02 items \\
\hline 4 o.d & $\begin{array}{l}369 \\
\text { items }\end{array}$ & 4 b.d & 03 items & 1 q.i.d. & 40 items & 2 p.r.n. & 53 items \\
\hline 5 o.d & $\begin{array}{l}280 \\
\text { items }\end{array}$ & 5 b.d & 00 items & 2 q.i.d. & 11 items & 3 p.r.n. & 300 items \\
\hline 4 p.r.n & 03 items & $\begin{array}{l}\text { On } \\
\text { demand }\end{array}$ & $\begin{array}{l}231 \\
\text { items }\end{array}$ & Stat. & $\begin{array}{l}706 \\
\text { items }\end{array}$ & & \\
\hline \multicolumn{8}{|c|}{ Parameter 8 - Frequency of various pre-packs used in the clinics } \\
\hline 1's & $\begin{array}{l}1142 \\
\text { items }\end{array}$ & 7's & 01 item & 25's & 09 items & 80 's & 06 items \\
\hline 2 's & 18 items & 10 's & $\begin{array}{l}332 \\
\text { items }\end{array}$ & 28's & $\begin{array}{c}1052 \\
\text { items }\end{array}$ & 84 's & 40 items \\
\hline 3's & 01 item & 14 's & $\begin{array}{l}176 \\
\text { items }\end{array}$ & 30 's & 23 items & & \\
\hline 4's & 45 items & 15 's & 39 items & 50 's & 03 items & & \\
\hline 6's & 03 items & 20 's & $\begin{array}{l}902 \\
\text { items }\end{array}$ & 56 's & 49 items & & \\
\hline \multicolumn{8}{|c|}{ Parameter 9 - Frequency of various dosage forms used in the clinics } \\
\hline Tablets & $65.4 \%$ & Injections & $4.74 \%$ & Capsules & $1.22 \%$ & $\begin{array}{l}\text { Fridge } \\
\text { Items }\end{array}$ & $0.17 \%$ \\
\hline Syrup & $6.63 \%$ & Food Items & $4.52 \%$ & $\begin{array}{l}\text { Nasal } \\
\text { Drops/ } \\
\text { Spray }\end{array}$ & $0.45 \%$ & Mixtures & $0.13 \%$ \\
\hline $\begin{array}{l}\text { Family } \\
\text { Planning }\end{array}$ & $6.02 \%$ & $\begin{array}{l}\text { Creams/ } \\
\text { Ointments }\end{array}$ & $2.92 \%$ & Powders & $0.36 \%$ & $\begin{array}{l}\text { Eye/Ear } \\
\text { Drops }\end{array}$ & $0.06 \%$ \\
\hline Vaccines & $5.52 \%$ & $\begin{array}{l}\text { Suspen- } \\
\text { sions }\end{array}$ & $1.47 \%$ & $\begin{array}{l}\text { External } \\
\text { Liquids }\end{array}$ & $0.34 \%$ & & \\
\hline
\end{tabular}

^One patient could visit a clinic more than once.

o.d.- once daily

b.d.- two times a day

4 t.i.d.- three times a day

"q.i.d.- four times a day

op.r.n.- as needed

-Stat.-immediately 
Table 3: Top five diagnoses analysis based on prevalence

\begin{tabular}{|c|c|c|c|c|c|c|}
\hline Diagnoses & Prevalence & $\begin{array}{l}\text { Total } \\
\text { medicine } \\
\text { cost } \\
\text { (Rands) }\end{array}$ & $\begin{array}{l}\text { Average } \\
\text { medicine } \\
\text { cost } \\
\text { (Rands) }\end{array}$ & CPI & $\begin{array}{l}\text { Prevalent } \\
\text { Gender }\end{array}$ & $\begin{array}{l}\text { Prevalent Age } \\
\text { group }\end{array}$ \\
\hline Tuberculosis & $\begin{array}{l}42.39 \% \\
(1423 \\
\text { items) }\end{array}$ & $\begin{array}{l}\text { R6 480.87 } \\
(32.94 \%)\end{array}$ & $\begin{array}{l}\text { R4.64 } \\
\pm 5.22\end{array}$ & 0.78 & $\begin{array}{l}\text { Males - } \\
61.11 \% \\
\text { (850 items) }\end{array}$ & $\begin{array}{l}>40<60 \text { years } \\
(53.03 \% / 70 \text { items })\end{array}$ \\
\hline $\begin{array}{l}\text { Family } \\
\text { planning }\end{array}$ & $\begin{array}{l}9.06 \% \\
\text { (304 items) }\end{array}$ & $\begin{array}{l}\text { R1 } 597.72 \\
(8.12 \%)\end{array}$ & $\begin{array}{l}\text { R5.26 } \\
\pm 1.43\end{array}$ & 0.89 & $\begin{array}{l}\text { Females - } \\
15.46 \% \\
\text { (304 items) }\end{array}$ & $\begin{array}{l}>12<19 \text { years } \\
(43.24 \% / 16 \text { items })\end{array}$ \\
\hline Hypertension & $\begin{array}{l}6.88 \% \\
(231 \text { items })\end{array}$ & $\begin{array}{l}\text { R3 935.38 } \\
(20.01 \%)\end{array}$ & $\begin{array}{l}\mathrm{R} 18.86 \\
\pm 15.94\end{array}$ & $2.91^{*}$ & $\begin{array}{l}\text { Females - } \\
9.56 \% \\
\text { (188 items) }\end{array}$ & $\begin{array}{l}>60 \text { years } \\
(46.43 \% / 13 \text { items })\end{array}$ \\
\hline $\begin{array}{l}\text { Vitamin } \\
\text { deficiency }\end{array}$ & $\begin{array}{l}5.63 \% \\
(189 \text { items })\end{array}$ & $\begin{array}{l}\text { R183.71 } \\
(0.93 \%)\end{array}$ & $\begin{array}{l}\text { R0.98 } \\
\pm 0.78\end{array}$ & 0.17 & $\begin{array}{l}\text { Males - } \\
62.57 \% \\
\text { (87 items) }\end{array}$ & $\begin{array}{l}>40<60 \text { years } \\
(2.27 \% / 3 \text { items })\end{array}$ \\
\hline Pain control & $\begin{array}{l}5.54 \% \\
(186 \text { items) }\end{array}$ & $\begin{array}{l}\text { R149.31 } \\
(0.76)\end{array}$ & $\begin{array}{l}\text { R0.77 } \\
\pm 1.02\end{array}$ & 0.14 & $\begin{array}{l}\text { Females - } \\
6.56 \% \\
\text { (129 items) }\end{array}$ & $\begin{array}{l}>60 \text { years } \\
(14.29 \% / 4 \text { items })\end{array}$ \\
\hline Total & $\begin{array}{l}69.50 \% \\
(2333 \\
\text { items })\end{array}$ & $\begin{array}{l}\text { R12 346.99 } \\
(62.77 \%)\end{array}$ & $\begin{array}{l}\text { R5.86 } \\
\pm 8.19\end{array}$ & 0.90 & \multicolumn{2}{|c|}{$\begin{array}{l}{ }^{*} \mathrm{CPI} \text { marked with a * } \text { sign are } \\
\text { considered to be significant }\end{array}$} \\
\hline
\end{tabular}

Table 4: General medicine analysis parameters

\begin{tabular}{|c|c|c|c|c|c|}
\hline $\begin{array}{l}\text { Total number } \\
\text { of } \\
\text { consultations }\end{array}$ & $\begin{array}{l}\text { Average } \\
\text { medicine } \\
\text { cost per } \\
\text { consultation } \\
\text { (Rands) }\end{array}$ & $\begin{array}{l}\text { Total number } \\
\text { of diagnoses }\end{array}$ & $\begin{array}{l}\text { Average } \\
\text { medicine } \\
\text { therapy cost } \\
\text { of diagnoses } \\
\text { (Rands) }\end{array}$ & $\begin{array}{l}\text { Average } \\
\text { number of } \\
\text { medicine } \\
\text { items }\end{array}$ & $\begin{array}{l}\text { Total number of } \\
\text { medicine items }\end{array}$ \\
\hline 2803 & $8.25 \pm 10.98$ & 3357 & $5.86 \pm 8.19$ & $1.67 \pm 1.12$ & 4691 \\
\hline $\begin{array}{l}\text { Average cost } \\
\text { of medicine } \\
\text { items } \\
\text { (Rands) }\end{array}$ & $\begin{array}{l}\text { Total cost of } \\
\text { medicine } \\
\text { items } \\
\text { (Rands) }\end{array}$ & $\begin{array}{l}\text { Patient per } \\
\text { consultation } \\
\text { ratio }\end{array}$ & $\begin{array}{l}\text { Percentage of } \\
\text { patients } \\
\text { receiving } \\
\text { medicine per } \\
\text { consultation } \\
(\%)\end{array}$ & $\begin{array}{l}\text { Number of } \\
\text { patients }\end{array}$ & $\begin{array}{l}\text { Patient per } \\
\text { budget/pharmaco- } \\
\text { logical/individual } \\
\text { group ratio }\end{array}$ \\
\hline $4.19 \pm 9.54$ & 19669.50 & $1: 2.13$ & 93.00 & 1313 & $1: 3.57$ \\
\hline
\end{tabular}


primary health care clinics; the results of which are depicted in Table 4.

\section{Conclusions based on general framework of medicine analysis}

The following conclusion can be made from the analysis of Table 4:

- The average number of medicine items per consultation was $1.67 \pm 1.12$ for all consultations [n=4 691].

- $\quad$ The average medicine cost per item of R4.19 \pm 9.54 is less than the cost in a private primary health care setting, where it was R5.79 \pm 1.58 [N=74 679] and less than R259.85 \pm 151.97 for a medical claim database (Plaath, 2003:52).

- The average cost of medicines per consultation was R8.25 \pm 10.98 [N= R19 669.50] for all medicines (including diagnoses for which medicines were not supplied).

\section{Summary of all parameters according to groups}

The parameters are summarised according to the top five budget groups, pharmacological group, individual medicine items and ATC class groups for all consultations in all clinics. The following criteria were also considered in the analyses; the total medicine cost $\geq 5 \%$ (R983.48), the total medicine costs in all clinics (R19 669.60/4 691 items), $\mathrm{CPI} \geq 1.5$, the average medicine cost per group, the frequency, gender and age group. The following trends were observed in Tables 5 to 8 .

\section{Conclusions of all parameters according to budget groups}

With reference to Table 5 for the top five budget groups in all clinics the following salient points are seen:

- These five budget groups accounted for $88.20 \%$ (R17 368.68) of the total medicine costs incurred and $84.08 \%$ (3930 items) of all medicine items used, in all clinics in Potchefstroom health district.

- Cardiovasculars had a significant CPI of 1.53 with an average medicine cost of $R 6.42 \pm 7.82$, as it constituted $20.47 \%$ (R4 026.85) of the medicine costs in all the clinics.

- Conclusions of all parameters according to therapeutic/pharmacological groups.

With reference to Table 6 for the top five pharmacological groups the following salient points are seen:

- The five pharmacological groups made up $76.59 \%$ (R14 886.08) of all medicine costs in the clinics and $61.97 \%$ (2 892 items) of all medicine items issued in the clinics.

- $\quad$ The CPI of antihypertensives was a high 1.89 and so was the average medicine cost at R7.85 \pm 8.50 , considering the fact that $19.09 \%$ (R3 699.22) of the total medicine costs in the clinic were in that group.

- The CPI of feeding and nutritional supplements was 3.12 and had a high average medicine cost of $R 12.99 \pm 3.84$.

\section{Conclusions of all parameters according to individual medicine items/product de- scription}

For the top five individual medicine items, the following salient facts become evident, as indicated in Table 7:

- The top five individual medicine items as indicated in Table 7 cost $45.19 \%$ (R7 562.33) of all the medicine costs incurred at the clinics in Potchefstroom health district during the study period.

- Perindopril $4 \mathrm{mg}$ tablets (28's pre-pack) had a high CPI of 4.46 and an average medicine cost of $\mathrm{R} 18.80 \pm 2.40$, which was high considering the fact that it constituted $6.47 \%$ (R1 133.69) of all costs in the clinics.

\section{Conclusions according to all parameters of the ATC classification}

With reference to Table 8, for the top five ATC classes in all the clinics in Potchefstroom health district, the following salient trends can be observed:

- $\quad$ The top five ATC classes constituted 3108 medicine items, which was $66.25 \%$ of all items (4 691 medicine items) according to the ATC class.

\section{Summary based upon therapeutic budget model prediction}

According to the therapeutic budget model the total 
Table 5: Top five budget group analyses based on total cost

\begin{tabular}{|c|c|c|c|c|c|c|}
\hline Budget group & $\begin{array}{l}\text { Medicine } \\
\text { Usage }\end{array}$ & $\begin{array}{l}\text { Total } \\
\text { medicine } \\
\text { cost (Rands) }\end{array}$ & $\begin{array}{l}\text { Average } \\
\text { medicine } \\
\text { cost } \\
\text { (Rands) }\end{array}$ & CPI & $\begin{array}{l}\text { Prevalent } \\
\text { Gender }\end{array}$ & $\begin{array}{l}\text { Prevalent Age } \\
\text { group }\end{array}$ \\
\hline Respiratory & $\begin{array}{l}1931 \\
\text { items } \\
(41.16 \%)\end{array}$ & $\begin{array}{l}33.06 \% \\
(\mathrm{R} 6503.59)\end{array}$ & $\begin{array}{l}\mathrm{R} 3.37 \\
\pm 4.25\end{array}$ & 0.80 & $\begin{array}{l}\text { Males - } \\
58.26 \%\end{array}$ & $\begin{array}{l}>19<40 \text { years } \\
53.03 \% / 977 \text { items }\end{array}$ \\
\hline Cardiovascular & $\begin{array}{l}627 \text { items } \\
(13.37 \%)\end{array}$ & $\begin{array}{l}20.47 \% \\
(\mathrm{R} 4 \text { 026.85) }\end{array}$ & $\begin{array}{l}\mathrm{R} 6.42 \\
\pm 7.82\end{array}$ & $1.53^{*}$ & $\begin{array}{l}\text { Females - } \\
82.29 \%\end{array}$ & $\begin{array}{l}>40<60 \text { years } \\
43.06 \% / 267 \text { items }\end{array}$ \\
\hline $\begin{array}{l}\text { Gastro- } \\
\text { intestinals }\end{array}$ & $\begin{array}{l}766 \text { items } \\
(16.33 \%)\end{array}$ & $\begin{array}{l}17.59 \% \\
\text { (R3 460.98) }\end{array}$ & $\begin{array}{l}\mathrm{R} 4.52 \\
\pm 6.05\end{array}$ & 1.08 & $\begin{array}{l}\text { Females - } \\
50.39 \%\end{array}$ & $\begin{array}{l}>19<40 \text { years } \\
46.39 \% / 354 \text { items }\end{array}$ \\
\hline Endocrines & $\begin{array}{l}347 \text { items } \\
(7.40 \%)\end{array}$ & $\begin{array}{l}10.65 \% \\
(\mathrm{R} 2 \text { 095.72) }\end{array}$ & $\begin{array}{l}\mathrm{R} 6.04 \\
\pm 3.91\end{array}$ & 1.44 & $\begin{array}{l}\text { Females - } \\
97.98 \%\end{array}$ & $\begin{array}{l}>19<40 \text { years } \\
67.09 \% / 157 \text { items }\end{array}$ \\
\hline Immunologicals & $\begin{array}{l}259 \text { items } \\
(5.52 \%)\end{array}$ & $\begin{array}{l}6.52 \% \\
\text { (R1 281.54) }\end{array}$ & $\begin{array}{l}\mathrm{R} 4.95 \\
\pm 8.16\end{array}$ & 1.18 & $\begin{array}{l}\text { Females - } \\
58.30 \%\end{array}$ & $\begin{array}{l}0<6 \text { years } \\
89.33 \% / 226 \text { items }\end{array}$ \\
\hline Total & $\begin{array}{l}3930 \\
\text { items } \\
(84.08 \%)\end{array}$ & $\begin{array}{l}88.20 \% \\
\text { (R17 368.68) }\end{array}$ & & 1.05 & \multicolumn{2}{|c|}{$\begin{array}{l}{ }^{*} \mathrm{CPI} \text { marked with } \mathrm{a}^{*} \text { sign are } \\
\text { considered to be significant }\end{array}$} \\
\hline
\end{tabular}

Table 6: Top five pharmacological/therapeutic groups analysis based on total cost

\begin{tabular}{|c|c|c|c|c|c|c|}
\hline $\begin{array}{l}\text { Pharmacological } \\
\text { group }\end{array}$ & $\begin{array}{l}\text { Medicine } \\
\text { Usage }\end{array}$ & $\begin{array}{l}\text { Total } \\
\text { medicine } \\
\text { cost } \\
\text { (Rands) }\end{array}$ & $\begin{array}{l}\text { Average } \\
\text { medicine } \\
\text { cost } \\
\text { (Rands) }\end{array}$ & CPI & $\begin{array}{l}\text { Prevalent } \\
\text { Gender }\end{array}$ & $\begin{array}{l}\text { Prevalent Age } \\
\text { group }\end{array}$ \\
\hline Antimycobacterials & $\begin{array}{l}1715 \\
\text { items } \\
(36.81 \%)\end{array}$ & $\begin{array}{l}30.81 \% \\
\text { (R5 972.49) }\end{array}$ & $\begin{array}{l}\text { R3.48 } \\
\pm 4.21\end{array}$ & 0.84 & $\begin{array}{l}\text { Males - } \\
59.69 \%- \\
850 \text { items }\end{array}$ & $\begin{array}{l}>19<40 \text { years } \\
55.19 \% \\
(775 \text { items })\end{array}$ \\
\hline Antihypertensives & $\begin{array}{l}471 \\
\text { items } \\
(10.11 \%)\end{array}$ & $\begin{array}{l}19.09 \% \\
\text { (R3 699.22) }\end{array}$ & $\begin{array}{l}\text { R7.85 } \\
\pm 8.50\end{array}$ & $1.89^{*}$ & $\begin{array}{l}\text { Females - } \\
81.58 \%- \\
186 \text { items }\end{array}$ & $\begin{array}{l}>40<60 \text { years } \\
49.79 \% \\
(232 \text { items })\end{array}$ \\
\hline $\begin{array}{l}\text { Feeding \& nutritional } \\
\text { supplements }\end{array}$ & $\begin{array}{l}213 \\
\text { items } \\
(4.54 \%)\end{array}$ & $\begin{array}{l}14.07 \% \\
(\mathrm{R} 2767.50)\end{array}$ & $\begin{array}{l}\text { R12.99 } \\
\pm 3.84\end{array}$ & $3.12^{*}$ & $\begin{array}{l}\text { Females - } \\
57.07 \%- \\
117 \text { items }\end{array}$ & $\begin{array}{l}0<6 \text { years } \\
47.92 \% \\
(133 \text { items })\end{array}$ \\
\hline Vaccines & $\begin{array}{l}247 \\
\text { items } \\
(5.27 \%)\end{array}$ & $\begin{array}{l}6.49 \% \\
(\mathrm{R} 1259.22)\end{array}$ & $\begin{array}{l}\mathrm{R} 5.09 \\
\pm 8.33\end{array}$ & 1.22 & $\begin{array}{l}\text { Females - } \\
59.63 \%-65 \\
\text { items }\end{array}$ & $\begin{array}{l}0<6 \text { years } \\
88.68 \% \\
(94 \text { items })\end{array}$ \\
\hline $\begin{array}{l}\text { Contraceptive } \\
\text { (injectables) }\end{array}$ & $\begin{array}{l}246 \\
\text { items } \\
(5.24 \%)\end{array}$ & $\begin{array}{l}6.13 \% \\
\text { (R1 187.65) }\end{array}$ & $\begin{array}{l}\text { R4.83 } \\
\pm 0.36\end{array}$ & 1.16 & $\begin{array}{l}\text { Females - } \\
100.00 \%- \\
246 \text { items }\end{array}$ & $\begin{array}{l}>19<40 \text { years } \\
78.29 \% \\
(119 \text { items })\end{array}$ \\
\hline Total & $\begin{array}{l}2892 \\
\text { items } \\
(61.97 \%)\end{array}$ & $\begin{array}{l}76.59 \% \\
\text { (R14 886.08) }\end{array}$ & & 1.24 & \multicolumn{2}{|c|}{$\begin{array}{l}{ }^{*} \mathrm{CPI} \text { marked with a * sign are } \\
\text { considered to be significant }\end{array}$} \\
\hline
\end{tabular}


Table 7: Top five individual medicine items/product description analyses based on total cost

\begin{tabular}{|c|c|c|c|c|c|c|}
\hline $\begin{array}{l}\text { Individual } \\
\text { medicine items }\end{array}$ & $\begin{array}{l}\text { Medicine } \\
\text { Usage }\end{array}$ & $\begin{array}{l}\text { Total } \\
\text { medicine } \\
\text { cost } \\
\text { (Rands) }\end{array}$ & $\begin{array}{l}\text { Average } \\
\text { medicine } \\
\text { cost }\end{array}$ & CPI & $\begin{array}{l}\text { Prevalent } \\
\text { Gender }\end{array}$ & $\begin{array}{l}\text { Prevalent Age } \\
\text { group }\end{array}$ \\
\hline $\begin{array}{l}\text { Rifampicin } \\
300 / 150 \mathrm{INH} \\
\text { tablets (20's pre- } \\
\text { pack) }\end{array}$ & $\begin{array}{l}535 \text { items } \\
(12.97 \%)\end{array}$ & $\begin{array}{l}14.32 \% \\
(R 2157.23)\end{array}$ & $\begin{array}{l}\mathrm{R} 4.03 \\
\pm 4.51\end{array}$ & 1.10 & $\begin{array}{l}\text { Males - } \\
66.17 \% \\
/ 354 \text { items }\end{array}$ & $\begin{array}{l}>40<60 \text { years } \\
62.99 \% \text { / } 3337 \\
\text { items }\end{array}$ \\
\hline $\begin{array}{l}\text { PVM maize meal } \\
\text { mix } 1 \mathrm{~kg}\end{array}$ & $\begin{array}{l}152 \text { items } \\
(3.68 \%)\end{array}$ & $\begin{array}{l}12.06 \% \\
(\mathrm{R} 2111.94)\end{array}$ & $\begin{array}{l}\mathrm{R} 13.89 \\
\pm 4.05\end{array}$ & $3.28^{*}$ & $\begin{array}{l}\text { Females - } \\
55.92 \% \\
/ 85 \text { items }\end{array}$ & $\begin{array}{l}0<6 \text { years } \\
53.95 \% / 82 \text { items }\end{array}$ \\
\hline $\begin{array}{l}\text { Perindopril 4mg } \\
\text { tablets (28's pre- } \\
\text { pack) }\end{array}$ & $\begin{array}{l}60 \text { items } \\
(1.45 \%)\end{array}$ & $\begin{array}{l}6.47 \% \\
\text { (R1 133.69) }\end{array}$ & $\begin{array}{l}\mathrm{R} 18.80 \\
\pm 2.40\end{array}$ & $4.46^{*}$ & $\begin{array}{l}\text { Females - } \\
71.67 \% \\
/ 43 \text { items }\end{array}$ & $\begin{array}{l}>60 \text { years } \\
51.67 \% / 31 \text { items }\end{array}$ \\
\hline $\begin{array}{l}\text { HREZ (Myrin } \\
\text { plus) tablets } \\
\text { (100's pre-pack) }\end{array}$ & $\begin{array}{l}250 \text { items } \\
(6.06 \%)\end{array}$ & $\begin{array}{l}6.40 \% \\
\text { (R1 119.83) }\end{array}$ & $\begin{array}{l}\mathrm{R} 4.46 \\
\pm 6.12\end{array}$ & 1.06 & $\begin{array}{l}\text { Males - } \\
67.20 \% \\
/ 168 \text { items }\end{array}$ & $\begin{array}{l}>19<40 \text { years } \\
55.60 \% / 139 \\
\text { items }\end{array}$ \\
\hline $\begin{array}{l}\text { Haemophillius } \\
\text { influenzae } \\
\text { conjunct vaccine } \\
\text { (10 dose) }\end{array}$ & $\begin{array}{l}47 \text { items } \\
(1.14 \%)\end{array}$ & $\begin{array}{l}5.94 \% \\
(\mathrm{R} 1039.64)\end{array}$ & R22.12 & $5.21^{*}$ & $\begin{array}{l}\text { Females - } \\
61.70 \% \\
/ 29 \text { items }\end{array}$ & $\begin{array}{l}0<6 \text { years } \\
100.00 \% / 45 \\
\text { items }\end{array}$ \\
\hline Total & $\begin{array}{l}1044 \\
\text { items } \\
(25.30 \%)\end{array}$ & $\begin{array}{l}45.19 \% \\
(R 7562.33)\end{array}$ & & $1.79^{*}$ & \multicolumn{2}{|c|}{$\begin{array}{l}{ }^{*} \mathrm{CPI} \text { marked with a * sign are } \\
\text { considered to be significant }\end{array}$} \\
\hline
\end{tabular}

Table 8: Top five ATC class analyses based on usage

\begin{tabular}{|l|l|l|l|}
\hline ATC Class & Medicine Usage & Prevalent Gender & Prevalent age group \\
\hline Antimycobacterials & $\begin{array}{l}1706 \text { items } \\
(36.56 \%)\end{array}$ & $\begin{array}{l}\text { Males - } \\
1024 \text { items / 34.17\% }\end{array}$ & $\begin{array}{l}>19<40 \text { years } \\
46.80 \% / 915 \text { items }\end{array}$ \\
\hline Vitamins & $\begin{array}{l}474 \text { items } \\
(10.04 \%)\end{array}$ & $\begin{array}{l}\text { Males - } \\
262 \text { items / 13.12\% }\end{array}$ & $\begin{array}{l}>19<40 \text { years } \\
13.81 \% / 270 \text { items }\end{array}$ \\
\hline $\begin{array}{l}\text { Sex hormones and genital } \\
\text { modulators of the genital }\end{array}$ & 306 items & Females - & $>19<40$ years \\
system & $(5.27 \%)$ & 306 items / 11.36\% & $7.93 \% / 155$ items \\
\hline Antihypertensives & 267 items & Females - & $>60$ years \\
& $(5.24 \%)$ & 215 items / 7.98\% & $26.80 \% / 93$ items \\
\hline Analgesics & 355 items & Females - & $>19<40$ years \\
& $(4.54 \%)$ & 233 items / 8.65\% & $5.32 \% / 104$ items \\
\hline Total & 3108 items & & \\
& $(66.25 \%)$ & & \\
\hline
\end{tabular}


Table 9: Budget allocation break-down in the clinics in Potchefstroom

\begin{tabular}{|l|l|l|l|l|l|}
\hline Clinic & $\begin{array}{l}\text { Budget } \\
\text { allocated } \\
\text { [Monthly] } \\
\text { Rand (R) }\end{array}$ & $\begin{array}{l}\text { Actual } \\
\text { expenditure } \\
\text { [Monthly] } \\
\text { Rand (R) }\end{array}$ & $\begin{array}{l}\text { Budget } \\
\text { allocated } \\
\text { [Yearly] } \\
\text { Rand (R) }\end{array}$ & $\begin{array}{l}\text { Projected } \\
\text { annual } \\
\text { expenditure } \\
\text { Rand (R) }\end{array}$ & $\begin{array}{l}\text { Percentage of } \\
\text { budget variance } \\
\text { (\%) }\end{array}$ \\
\hline 1 & 11038.50 & 15710.58 & 132462.00 & 188527.00 & 142.33 \\
\hline 2 & 10574.42 & 44942.70 & 126893.00 & 539312.00 & 425.01 \\
\hline 3 & 38823.25 & 55133.10 & 465979.00 & 661597.00 & 142.01 \\
\hline 4 & 13142.50 & 27302.66 & 157710.00 & 327632.00 & 207.34 \\
\hline 5 & 8303.50 & 26836.26 & 99702.00 & 322035.00 & 323.19 \\
\hline 6 & 12085.08 & 40704.18 & 145021.00 & 488450.00 & 336.81 \\
\hline Total & 93967.25 & 210629.48 & 1127607.00 & 2607357.00 & 231.23 -Average \\
\hline
\end{tabular}

projected annual expenditure for all public Primary Health Care (PHC) clinics in Potchefstroom was R2 607357.28 , which was $231.23 \%$ above the allocated annual budget of R1 183 732.00. The Potchefstroom Health District has increased the budget based upon the recommendations of this study and currently a consistent trend in their budgetary allocations was noticed as observed in Table 9.

\section{Conclusions based on the therapeutic budget model}

The following conclusions can be formulated from the results based on Table 9:

- The existing budget allocation is not sufficient to manage the procurement of medicines in the public primary health care clinics in Potchefstroom Health district.

- The therapeutic budget model would help in identifying areas of specific need in medicine demand-procurement-expenditure strategies.

\section{RECOMMENDATIONS}

The following recommendations are made, based on an analysis of the results and related conclusions using the data in Tables 2 and 3, namely:

- The improvement of the documentation system and data capturing mechanism for patients in all the clinics.

- An investigation as to why hypertension has a prevalent percentage in $6.88 \%$ of all consultations in Potchefstroom Health district.

- An investigation as to whether there is an overuse and tendency to prescribe vitamins and mineral supplements to the patients regardless of the clinical merit.

The following general recommendations, based on reviewing all the conclusions of the data in Tables 4, 5, 6, 7 and 8 are aimed to effectively control diseases and outcomes, in the public primary health care clinics of Potchefstroom health district:

- An investigation as to whether there is an overuse and tendency to prescribe feeding and nutritional supplements among patients in the age group of $0<6$ years, regardless of the clinical merit, based on the conclusions drawn from the pharmacological group classification system; as malnutrition was not seen as one of the top five disease/condition/diagnoses.

- A cost-effective analysis of injectable contraceptives versus oral contraceptives, based on the pharmacological groups classification system conclusions.

- A cost-effectiveness analysis of Perindopril tablets in managing hypertension and a medicine usage study of antihypertensives in particular, to investigate the possibility of overuse of antihypertensives in the clinics; based on the conclusions drawn from the parameters for the individual medicine items.

- A clinical investigation into whether there is a possibility of replacing the PVM maize meal 
mix with cost-effective yet therapeutically equivalent items, based on the conclusions drawn from the parameters for the individual medicine items.

The implementation of a therapeutic budgeting system is recommended based on the conclusions drawn from Table 9, to achieve better resource management in both the public and private health care settings and also to achieve the following:

- Proper preparation and planning of budgetary policies in a phased manner based on scientific evidence (direct correlation with medicine usage).

- Evaluation of budgetary compliance, costefficiency of therapy and Standard Treatment Guideline (STG)/Essential Drug List (EDL)/ formulary compliance.

- Better procurement strategies based on demand, expenditure and inventory control.

- Better delivery and maintenance of quality health care by evaluating operational and clinical policies.

The above recommendations are also a motivation for follow-up research on therapeutic budget modelling, and increasing the scope of study, to include more geographical areas (health districts, regions, provinces, for example) and levels of health care (district hospital, provincial hospital, for example).

\section{ACKNOWLEDGEMENTS}

The authors would like to acknowledge the following participants and institutions for their co-operation and input:

- Mr Mahesh Roopa, The District Manager of Health and other staff at Potchefstroom District Health office.

- The staff of the public primary health care clinics in Potchefstroom Health district.

- The School of Pharmacy, North-West University (Potchefstroom campus).

\section{REFERENCES}

ANDREWS, G \& PILLAY, Y 2005: South African Health Review 2005. Priorities for the national health system (2004-2009), contributions towards building a model developmental state in South
Africa. (In: Ntuli, A ed. South African health review. Durban: Health Systems Trust).

BLECHER, M 2006: Recent trends in public health care funding and expenditure in South Africa. Podium presentation in the scientific session 5D: Equity of the $3^{\text {rd }}$ Public Health conference, at Midrand, South Africa on $17^{\text {th }}$ May, 2006.

BLOK, FC; ZWEYGARTH, M \& SUMMERS, R 2002: A formula to calculate budgetary allocations to health districts in a South African province. Essential Drugs Monitor, 31:32-33.

BUCH, E 2000: The health sector strategic framework: A review. (In: Ntuli, A ed. South African health review. Durban: Health Systems Trust).

COETZER, L 2002: Provincial budget break-up. [E-mail]. From: “Leona Coetzer" coetzerl@comed.pwv.gov.za. Pharmacist, Pharmaceutical expenditure domain, Department of Health. Pretoria. To: “George John” fptgkj@puknet.puk.ac.za. Researcher, Pharmacy Practice, PU for CHE. [Date of communication: 12 March 2002]. COMMITTEE OF INQUIRY: See South Africa. 1995:

DEPARTMENT OF HEALTH: See South Africa. 2001 a, 2001b and 2004a.

DSM: See South Africa. 2001a.

JOHN, GK 2003: Pharmacy in South Africa: An overview. Plenary lecture to the Indian Pharmaceutical Congress (IPC) in Chennai, India on 19 December 2003.

LEEDY, PD 1997: Practical research: Planning and design; $6^{\text {th }}$ edition. Upper Saddle River: NJ Merrill.

KIRIGIA, J 2005: Health economics: Scope and application in the African region. Health economics, getting value for money. African Health Monitor; 6(1):2-5.

MAIL \& GUARDIAN 2006: Provinces spending more of budgets on average. News article on 03 May 2006. Available from: http:// www.mg.co.za (Date of access: 3 May 2006).

MANUEL, T 2004: Budget speech, 18 February 2004. (ISBN: 0621-35038-9). Pretoria: Communication Directorate National Treasury.

MCINTYRE, D; BABA, L \& MAKAN, B 1998: Equity in public health care financing and expenditure in South Africa. (In: Ntuli, A ed. South African health review. Durban: Health Systems Trust). NEUMAN, WL 2000: Social research methods: Qualitative and quantitative approaches; $4^{\text {th }}$ edition. Boston: Allyn \& Bacon. PHASA. See South Africa, 2006:

PLAATH, JV 2003: A retrospective analysis of the usage of cephalosporines: A pharmacoeconomic approach. Potchefstroom: PU for CHE (Dissertation-M Pharm).

SOUTH AFRICAN HEALTH REVIEW. See Andrews, G \& Pillay, Y 2005.

SERFONTEIN, JHP 2004: Verbal communication with author. Research Director, Pharmacy Practice, School of Pharmacy, Faculty of Health Sciences, North-West University (Potchefstroom cam- 
pus): Potchefstroom (Notes in possession of author).

SOUTH AFRICA 1995: Committee of inquiry into the national health insurance system: Restructuring the national health system for universal primary health care. Executive summary. Pretoria: Government printer.

SOUTH AFRICA 2001a: Department of Health. Drug Supply management document. Workshop held in August 2001 at Centurion Lake Hotel, Pretoria. 1-12, 32.

SOUTH AFRICA 2001b: Department of Health. Northwest Province quarterly budget report prepared by Vuna Healthcare Logistics (VHL) on PHC management information.

SOUTHAFRICA 2004a: Department of Health. Patient's rights charter. [Web] http://www.ncf.org.za/docs/patientrights.html (Date of access: 30 August 2004).

SOUTHAFRICA 2004b: Health Statistics and Health financing. Health System Trust. [Web] http://www.hst.org.za/healthstats/106/data (Date of access: 30 August 2004).

SOUTH AFRICA 2006: Public Health Association of South Africa. "Making Health systems work". The $3^{\text {rd }}$ Public Health conference, at Midrand, South Africa, 15-17 May 2006.

STEYN, AGW; SMIT, CF; DU TOIT, SHC \& STRASHEIM, C 1999: Modern Statistics in Practice; $1^{\text {st }}$ edition. Pretoria: JL van Schaik. VAN RENSBURG, DV; VILJOEN, R; HEUNIS, C; VAN RENSBURG, EJ \& FOURIE, A 2000: Primary health care facilities survey. South African Health Review, 2000.Durban: Health Systems Trust (HST). WHO ACTION PROGRAMS ON ESSENTIAL DRUGS 1993: How to investigate drug use in health facilities. Geneva: Department of Essential Drugs and Medicines Policy, WHO. 